\title{
Metronidazole and Niridazole combined with Dehydroemetine in Treatment of Children with Amoebic Liver Abscess
}

\author{
J. N. SCRAGG and S. J. POWELL \\ From the Departments of Paediatrics and Child Health, and of Medicine, University of Natal; \\ and the Amoebiasis Research Unit, ${ }^{\star}$ Durban, South Africa
}

\begin{abstract}
Scragg, J. N., and Powell, S. J. (1970). Archives of Disease in Childhood, 45, 193. Metronidazole and niridazole combined with dehydroemetine in treatment of children with amoebic liver abscess. Metronidazole combined with dehydroemetine cured 13 of 15 children with amoebic liver abscess. An alternative combination of niridazole with dehydroemetine produced cure in 13 of 14 children. No relapses were observed. Electrocardiographic changes were noted in 2 of the first group and in 5 of those who received the second regimen. The results are similar to those obtained with emetine preparations combined with chloroquine. Either metronidazole or niridazole are effective substitutes for chloroquine and of these preparations metronidazole is preferred.
\end{abstract}

We have shown that emetine hydrochloride or dehydroemetine combined with chloroquine are more effective than any of these drugs when used alone for the treatment of children with amoebic liver abscess (Scragg and Powell, 1966; 1968). Though the results with these combinations showed an improvement on earlier studies (Scragg, 1960), there is still an appreciable mortality and the disease bears a worse prognosis in children than in adults.

In recent years clinical trials have shown 2 new amoebicides, niridazole and metronidazole, to be most effective in adults with amoebic liver abscess (Powell et al., 1966a; 1966b; Powell, Wilmot, and Elsdon-Dew, 1967). Significant toxic effects have not been demonstrated with metronidazole, but neurological toxicity and ECG changes have limited the use of niridazole as an amoebicide in adults (Powell, Wilmot, and Elsdon-Dew, 1969). However, in African children the latter drug has been extensively used, without adverse effects,

\footnotetext{
Received 18 August 1969.

«The Amoebiasis Research Unit is sponsored by the following bodies: the South African Council for Scientific and Industrial Research; the Natal Provincial Administration; the University of Natal; and the United States Public Health Service (Grant AI 01592).
}

for the treatment of urinary tract bilharziasis (Powell et al., 1968), and it may therefore retain a place in the treatment of amoebiasis in paediatric practice.

The following trial was designed to assess and compare the efficacy of metronidazole and niridazole in combination with dehydroemetine in the treatment of children with amoebic liver abscess.

\section{Material and Methods}

Studies were made on 29 African children, their ages ranging from 4 months to 9 years. The diagnosis of amoebic liver abscess was confirmed by the aspiration of characteristic pus from the liver in all patients; in 20 of the 29 aspirates trophozoites of Entamoeba histolytica were identified. In all patients the amoebic gel-diffusion test was positive.

All patients received dehydroemetine, $2 \mathrm{mg} . / \mathrm{kg}$. per day by subcutaneous injection for 10 days, and in addition were randomly placed on either metronidazole, $50 \mathrm{mg} . / \mathrm{kg}$. per day, or niridazole, $25 \mathrm{mg} . / \mathrm{kg}$. per day, orally for 10 days. In 25 patients repeated aspirations of the liver were required, and in 4 surgical drainage of the abscess was eventually necessary, but no additional amoebicides were given.

\section{Results}

The results are summarized in the Table. 
TABLE

Results of Treatment

\begin{tabular}{l|c|c|c|c}
\hline \multicolumn{1}{c|}{ Drug } & $\begin{array}{c}\text { No. of } \\
\text { Patients }\end{array}$ & $\begin{array}{c}\text { No. of } \\
\text { Cures }\end{array}$ & $\begin{array}{c}\text { No. of } \\
\text { Deaths }\end{array}$ & $\begin{array}{c}\text { No. of } \\
\text { Relapses }\end{array}$ \\
\hline $\begin{array}{l}\text { Metronidazole } \\
\text { Niridazole }\end{array}$ & 15 & 13 & 2 & 0 \\
14 & 13 & 1 & 0 \\
\hline
\end{tabular}

Note: Both drugs were given in combination with dehydroemetine.

No relapses were observed during a follow-up period of 3 months.

Necropsy findings. It will be noted that 2 patients who received metronidazole combined with dehydroemetine died. One, a marasmic 16-month-old infant, appeared to be responding satisfactorily until the 12th day when he developed an Esch. coli septicaemia. He died 3 days later; necropsy showed multiple circumscribed liver abscesses with the liver adherent to the stomach and diaphragm. Amoebic ulceration with necrosis of all layers of the bowel wall extended from the caecum to the rectum. The second patient, aged 4 months, was extremely ill on admission with active dysentery and increasing jaundice. Shortly before death on the 8th day he developed meningitic signs. Permission for necropsy was refused.

One patient, aged 2 years, who received niridazole combined with dehydroemetine died on the 7th day. Though 2 aspirations had yielded $240 \mathrm{ml}$. amoebic pus, at necropsy a large right lobe liver abscess was found.

ECG findings. ECG recordings were obtained on admission, and on the 10th and 20th days, in 13 patients in each of the 2 groups. $T$ wave inversion was present at 10 days in 2 of those who received the metronidazole regimen but had disappeared by 20 days. 4 of the patients given niridazole developed $T$ wave inversion and in 2 of them the changes were still present at 20 days. In a fifth child in this group ventricular premature beats were observed at 10 days. With the possible exception of the latter case, the ECG changes were slight and no other arrhythmias, conduction defects, or significant tachycardia were observed.

\section{Discussion}

The results of these 2 trials are similar and do not differ significantly from those previously reported with either emetine hydrochloride or dehydro- emetine combined with chloroquine (Scragg an Powell, 1968). It is evident that metronidazole or niridazole can be substituted in place of chloroquine and are to be preferred since they are more effectiv $\vec{S}$ in eradicating intestinal infection, and have bees found to be superior in the treatment of adults with amoebic liver abscess (Powell et al., 1967; Powello 1969).

Neither intolerance nor toxicity were problem $\$$ with niridazole in the present trial, and in childrep combination with dehydroemetine resulted in milder ECG changes than the severe abnormalities observed in adults (Powell, 1967). Neverthelessy since metronidazole is a fully satisfactory alternative which has not been found to possess toxicity in ant age-group, this appears to be the drug of firsin choice.

In adults metronidazole, in the absence of an $\overrightarrow{\mathrm{y}_{0}}$ other drug therapy, is extremely effective in curing amoebic liver abscess (Powell et al., 1967), and this is probably equally true in children. However, because the condition is frequently so serious in the very young we are reluctant to abandon parenteraf. emetine preparations entirely, and it is prudent t $\overrightarrow{0}$ use these in combination with metronidazole ip severely ill cases. As in our previous trial, the clinical condition of those who died and the necropsy findings suggested that the outcome was hopeless from the start of treatment. For this reason, though modern amoebicides, prompo diagnosis, adequate aspiration, and surgical drainage in selected instances have done much to improve the prognosis during the past decade, the mortality of amoebic liver abscess is likely to remain highe in infants than in adults regardless of the nature of the therapy.

We wish to thank the registrars of the Department of Paediatrics and Child Health, University of Nata who assisted in this study, Dr. H. Wannenburg, Medica䟥 Superintendent, King Edward VIII Hospital, Durba物 for facilities, and Messrs. May and Baker Ltd., and Cibج Ltd., for supplies of metronidazole and niridazole.

\section{REFERENCES}

Powell, S. J. (1967). The cardiotoxicity of systemic amebicide American fournal of Tropical Medicine and Hygiene, 16, 447. $\sigma$ (1969). Metronidazole in the treatment of amoebic liver abscess. Medicine Today, 3 (1), 85.

_, MacLeod, I., Wilmot, A. J., and Elsdon-Dew, R. (1966a Ambilhar in amoebic dysentery and amoebic liver absces\$ Lancet, 2, 20.

$\longrightarrow,-,-$, and - (1966b). Metronidazole in amoebid dysentery and amoebic liver abscess. Lancet, 2, 1329.

-, Scragg, J. N., Rubidge, C. J., and Naidoo, B. T. (1968 Further trials of niridazole in urinary tract bilharziasis. Sou African Medical fournal, 42, 760. 
—, Wilmot, A. J., and Elsdon-Dew, R. (1967). Further trials of metronidazole in amoebic dysentery and amoebic liver abscess. Annals of Tropical Medicine and Parasitology, 61, 511 . - , and - (1969). The use of niridazole alone and in combination with other amoebicides in amoebic dysentery and amoebic liver abscess. Annals of the New York Academy of Sciences, 160, 749.

Scragg, J. N. (1960). Amoebic liver abscess in African children. Archives of Disease in Childhood, 35, 171.
- , and Powell, S. J. (1966). Emetine hydrochloride and chloroquine in the treatment of children with amoebic liver abscess. Archives of Disease in Childhood, 41, 549.

- and - (1968). Emetine hydrochloride and dehydroemetine combined with chloroquine in the treatment of children with amoebic liver abscess. Archives of Disease in Childhood, 43, 121.

Correspondence to Dr. S. J. Powell, P.O. Box 1035, Durban, South Africa. 